Journal of Philosophy and Culture, Vol. 3, No. 2 June 2006

\title{
PROFILING A MODEL FOR THE ADMINISTRATION OF ZAKAT IN A MULTI-RELIGIOUS SOCIETY: THE CASE OF SOUTH-WESTERN NIGERIA
}

\author{
A. A. Akanni \\ Department of Religious Studies \\ Olabisi Onabanjo University \\ Ago Iwoye
}

\section{Introduction}

Islam is undoubtedly one of the world's leading religions today with adherents cutting across all the continents. It is even said to be the world's fastest-growing religion ${ }^{1}$. The practice of its tenets therefore is worldwide regardless of whether the adherents of the religion are the majority or constitute the minority group where they live. Like other tenets of Islam, adherents are expected to practise zakat, an institution meant to generate funds from the wealthy Muslims for the upkeep of the poor ones among them. A major condition for validity of the practice of this pillar of Islam requires that it is managed or administered by the machineries of the state. As $\mathrm{Ali}^{2}$ however contends, most Muslims today live under nonMuslim governments which do not, cannot and will not undertake the collection and disbursement of zakat for them. Muslims under this condition, therefore, not only find it difficult to practise this social institution of Islam but also use this political condition as an excuse for not practising zakat with the implications that both the benefactors and the beneficiaries are denied the reward of its practice. This paper is therefore an attempt to profile a model for the administration 


\section{A. A. Akanni}

of this all-important zakat in a multi-religious society using the southwestern Nigeria as a case study. It aims at helping Muslims who live under non-Muslim governments to practice zakat as demanded by the Shariah. Away from the usual theoretical review emphasising the significance and role of zakat in an economy, this humble attempt emphasises a practical step by step approach to operationalising zakat in a socio-political setting that is not Islamic. That notwithstanding, a few lines will be written on the types, significance and administration of zakat in Islam.

\section{Zakat: Types, Significance and Administration in Islam}

A major instrument Islam aims at using to alleviate poverty in human society is the zakat. It is the Islamic tax instituted for the amelioration of the suffering of the poor in the Islamic society. According to the holy Prophet Muhammad (SAW), it is to be taken from the rich and given to the poor ${ }^{3}$. It is paid on the surplus of wealth, which is left over after the passage of year. It is thus a payment on the accumulated wealth. The minimum standard of surplus wealth over which zakat is charged is known as nisab. Leaving aside animals and agricultural yield, zakat is paid at almost a uniform rate of $2 \frac{1}{2}$ per cent.

Zakat is so important in Islam that it is made one of the five pillars of Islam. In fact, it is the third, according to the order of listing them by the prophet Muhammad (SAW), coming before pilgrimage to Makkah and Ramadan fasting. In the Glorious Qur'an (e.g. 73:20), its payment is mentioned about 82 times along with As-Salat (Ritual Prayer) which is said to be the first thing to be accountable for on the Day of Judgement, the perfection of which brings other acts and 


\section{A Model for the Administration of Zakat}

righteousness of man to glory and reward and the failure of which brings them into vanity ${ }^{4}$. In Islamic theology, nonpayment of zakat amounts to apostasy. This is because Qur'an 9:103 ordered the Prophet Muhammad (SAW) to "take sadaqah from them in order to purify them and sanctify them with it". It was for this reason that Abu Bakr, the successor of the Prophet Muhammad (SAW) to the leadership of the Muslim Empire prosecuted some Muslims who refused to pay it following the demise of the Prophet ${ }^{5}$.

The significance of zakat in Islam has also led some Muslim countries like Yemen, Saudi Arabia, Libya, Sudan, Pakistan, Iran, Bangladesh, Bahrain and Iraq to establish special institutions for its collection and disbursement ${ }^{6}$. Even in Malaysia in 1991, government was being urged to legislate for the giving of zakat with penalties of up to three years in jail, £1800 fine and six strokes of cane for non- payment ${ }^{7}$. In fact, mosques, organisations and individuals are making conscious and concerted efforts to collect and disburse zakat in almost every country where there is a significant number of Muslims. As a further demonstration of the importance Islam attaches to zakat, it is legislated that the property inherited by orphans should be invested in trade so that zakat might not consume $\mathrm{it}^{8}$. One will appreciate this position of Islam if one considers how well Islam protects the property of the orphan from mismanagement in the hands of his or her guardian (Qur'an 4:2-6). Yet, Islam still imposes zakat on it. The essence of this is to ensure that the wealth of the Muslim nation keeps circulating. All these underscore the significance of zakat in the polity of Islam.

To further show how important zakat is in Islam, it is further legislated that it should be paid on wealth lent out even 


\section{A. A. Akanni}

though this has to be delayed until the debt is recovered in the case in which the chances of recovery are remote. Where the chances of recovery are high, the debts owed the payer of zakat is to be included for the assessment of the cash when it is due . It is even said that if the zakat that is due on one's wealth is lost after it has been deducted but before it is paid to the deserving recipients, it should be repaid fully. In fact, arrears of zakat must be paid as it is done in As - Salat (Ritual Prayer) and Sawm (Fasting) no matter how long and no matter the circumstances that led to its non-payment be they forgetfulness, disorder, ignorance etc ${ }^{10}$. According to Islamic theology, zakat is binding on every Muslim, male or female, adult or minor, sane or insane who possesses any of the items of wealth from which zakat is due and whose wealth is not less than the minimum upon which it is imposed. Ambali writes further:

A Muslim who is not in control of his faculty and minors cannot make valid prayer (Salat) but they are liable to pay zakat if they own property from which it is due...Although these categories of Muslims, especially the mentally challenged are not liable to discharge religious duties as they are not accountable for their misdeeds, the caretakers of their wealth shall be held responsible if they fail to pay zakat from the wealth ${ }^{11}$.

The institution of zakat is based on the belief of Islam that, though, men may be given equal opportunities to employ the numerous bounties of Allah to earn a meaningful livelihood (Qur'an 5: 87-88), some are bound to earn more than others because of the differing talents of personality, intellect, health, strength and spirit. Thus, Islam enjoins the payment of zakat as a means of redistributing income so that, in the language of the Qur'an, "wealth does not circulate only among the rich" 


\section{A Model for the Administration of Zakat}

(Qur'an 59:7). This, Islam envisages, will reduce, if not eradicate the gross inequalities of income and wealth that would result from such differences in ability to utilise God's resources, the consequences of which is social disharmony. Rather than perpetually having two distinct classes of people in the society where capitalism, an economic system that permits individuals to maximize profits operates or rewarding everybody equally irrespective of individual's ability as with socialism, Islam legislates that one - fortieth of the wealth of every rich Muslim be remitted to the public treasury of the Islamic state for utilization to enhance standard of living that is humane, respectable and in harmony with the dignity of man envisaged for every member of the society. For zakat to play its role in the society, it is legislated that the zakat of one city should not be taken to another city except in cases of greater needs ${ }^{12}$.

According to the traditional list of pristine Islam, zakat is payable on five categories of items. These include zakat on livestock, zakat on farm produce, zakat on gold and silver (i.e cash), zakat on merchandize and zakat on buried treasures and mines ${ }^{13}$. Modern views have, however, been expressed on this fiscal policy of Islam. In the words of Weeramantry ${ }^{14}$, interesting discussions have arisen in the context of modern finance concerning the forms of wealth to which zakat applies. Shares and securities, insurance policies, provident funds and machinery, being forms of wealth not known at the time of the foundation of Islam, have provoked much academic discussion. For example, Pippin asks: "Is zakat to be paid on types of property unknown in classical Islamic times? Just what do stock certificates represent? Should the tax be paid in stock certificates or in cash? At what percentage?"15 


\section{A. A. Akanni}

Gusau in his review of literature on relevant areas concerning zakat in theory and practice writes that there has been a lot of controversy among scholars as to whether or not the coverage, rates, nisab and beneficiaries should remain as they were in the days of Prophet Muhammad and his companions ${ }^{16}$. According to Gusau, the argument for this extension is the desire for justice among all holders of wealth and the necessity to tap all available resources for the fulfillment of the weak members of the society. He writes:

These differences continue up-till today, although there seems to be a shift of opinion in favour of extending the coverage of zakat...There is insistence on the part of early ulema as well as contemporary ones...that rates of zakat should remain fixed forever, because they have textual and ijma' backing. However, some contemporary Islamic economists, possessed by the zeal for redistributive justice, have argued for its fixed rate on the grounds that such fixity has textual backing,... Some Islamic economists have argued for its adjustment and flexibility to attain uniformity in the $n i s a b$ and to make more funds available for the support of the poor and the needy and for fiscal policy purposes. ${ }^{17}$

Ahmad observes that one of the conditions for the nisab warranting the payment of zakat is that it must be productive potentially or actually i.e., it must be of lasting value ${ }^{18}$. Silver, gold and all other mediums of exchange potentially represent a means for the further increase of wealth. Ahmad writes further that the wealth consisting of herds and flocks of pasturing domestic animals or of the things, representing articles of trade and commercial capitals are of the nature of the real productive land, whether actually or potentially so. It is for this reason that Ambali advises the wage earners to take clue logically from the principle that governs the traders to fix a month in the year 


\section{A Model for the Administration of Zakat}

from which they will be paying zakat ${ }^{19}$. Like their business counterparts, the assessment should be based on what they have in bank, current or savings accounts, shares, bonds, cash, local or foreign currency notes on hand and recoverable debt or arrears of salaries and allowances. If the total sum during the appointed month is up to nisab, they pay. If it falls short of $n i s a b$, they are not liable to pay it that year. He continues further that companies are not liable to pay zakat, even if every shareholder is a Muslim. They are individually liable to pay zakat. "Each person is liable to the tune of his share and individually liable to pay zakat based on his investment" 20 .

According to Ambali, it is the consensus of the jurists that the property owners who hired out their houses should pay zakat according to the rental values of the property, if they are up to nisab and they are in his possession for one year ${ }^{21}$. The area of difference is effective date of calculation of one year. Imams Abu Hanifah and Malik, for example, were of the opinion that the effective date should begin when the tenancy for which the payment was collected expires. This is because it is only then that the services have been rendered and the money paid becomes owner's property. Imam Ahmad b. Hambali was of a different view. According to him, milk of the rental fees has become owner's property since the contract was solemnised and sealed - so the effective date of calculation of one year should begin from the effective date of the contract. He concludes:

The latter seems to suit Nigerian situation better than the former where property owners collect the rents in advance and the chances of refunds do not arise when the tenants fail to utilize the property. But the opinion of Imam Malik and Abu Hanifah... suits the situation where payments of the rents are made after the utilization, the effective date goes by 


\section{A. A. Akanni}

the payment rather than the date of the contract solemnisation. The Landlords, who collect the rent on monthly basis, whether in arrears or in advance, have to wait until the time they have appointed to calculate the $z_{a k a t^{22}}$.

Details of what percentage is paid on each of these traditional categories of items are given by Balogun in the Table below but it is worth noting that these vary from $2 \frac{1}{2}$ to 20 per cent of amounts in excess of certain stipulated limits called nisab.

Table: Schedule of Zakat

\begin{tabular}{|c|c|c|c|}
\hline & $\begin{array}{l}\text { Wealth on which } \\
\text { Zakah is payable }\end{array}$ & $\begin{array}{l}\text { Amt that determines the } \\
\text { payment of Zakah (nisab) }\end{array}$ & Rate of Zakah \\
\hline 1. & Agricultural produce & $\begin{array}{l}5, \text { Awsuq }(653 \mathrm{~kg}) \\
\text { per harvest* }\end{array}$ & $\begin{array}{l}5 \% \text { produce for irrigated land; } \\
10 \% \text { from rain-fed land. }\end{array}$ \\
\hline 2. & $\begin{array}{l}\text { Gold, silver ornaments } \\
\text { of gold and silver. }\end{array}$ & $\begin{array}{l}85 \text { grams of gold or } \\
595 \text { grams of silver* }\end{array}$ & 2.5 percent of value \\
\hline 3. & $\begin{array}{l}\text { Cash in hand or at } \\
\text { Bank }\end{array}$ & $\begin{array}{l}\text { Values of } 595 \text { grams } \\
\text { of silver* }\end{array}$ & 2.5 percent of amount \\
\hline 4. & Trading goods & $\begin{array}{l}\text { Value of } 595 \text { grams } \\
\text { of silver* }\end{array}$ & 2.5 percent value of goods \\
\hline 5. & Cows and Buffaloes & 30 in number & $\begin{array}{l}\text { For every } 30 \text {, one } 1 \text {-year-old } \\
\text { for every } 40 \text {, one } 2 \text {-year-old }\end{array}$ \\
\hline 6. & Goats and sheep & 40 in number & $\begin{array}{l}\text { One for first } 40 \text {; } \\
\text { two for } 120 \text {, three for } 300 \text {; } \\
\text { one more for every } 100\end{array}$ \\
\hline 7. & Produce of mines & Any quantity & $20 \%$ of values of produce \\
\hline 8. & Camels & 5 in number & $\begin{array}{l}\text { (a) up to } 24,1 \text { sheep or goat } \\
\text { for each } 5 \text { camels } \\
\text { (b) } 25-35 \text {, one } 1 \text {-year-old } \\
\text { she-camel } \\
\text { (c) } 36-45 \text {, one } 2 \text {-year-old } \\
\text { she-camel } \\
\text { (d) } 46-60 \text {, one } 3 \text {-year-old } \\
\text { she-camel } \\
\text { (e) } 61-75,4 \text {-year-old } \\
\text { she-camel } \\
\text { (f) } 76-90 \text {, two } 2 \text {-year-old } \\
\text { she-camels } \\
\text { (g) } 91-120 \text {, two } 3 \text {-year-old } \\
\text { she-camels } \\
\text { (h) } 121 \text { or more, one } 2 \text {-yr-old } \\
\text { she-camel for every add. } 50\end{array}$ \\
\hline
\end{tabular}

Adopted from Balogun 


\section{A Model for the Administration of Zakat}

From the above, one can see that the quantity on each item of wealth is fixed. According to Ambali, to offer less is comparable to offering less than four rak'at for Zuhr, 'Asr or Isha' $i$ or less than three rak'at for Maghrib. It is as bad as breaking Ramadan fasting before sunset or to perform Hajj without observing wuquf at "Arafat ${ }^{24}$. It is on this ground that Akanni found out that the sighting of the new moon is as necessary for zakat (and seven other tenets of Islam) as it is for Ramadan fast ${ }^{25}$. He contends that if the new moon is wrongly sighted, it means the compulsory religious tax will be paid some days less or some days more than a year and that means that the zakat is not paid according to Shari'ah. Besides, where an animal of one or two years old is to be paid, the wrong visibility of the new moon will result in using an unworthy animal for the payment of zakat as it will not be of the expected $\operatorname{age}^{26}$.

According to Ambali, to calculate the nisab equivalent of banknotes such as naira, riyal, pound sterling, dollar etc, the beacon remains the value of gold or silver of dinar and dirham which is 84.8 grams. World Bank regularly releases the prizes of gold and other commodities ${ }^{27}$. Nigeria, like other countries, gives the equivalent of naira to dollar to guide on the exchange rate. These are the data required to calculate and know the value of nisab at any given time. An example of the recent calculation of zakat, which Ambali made in October 2006, was two hundred and forty nine thousand, four hundred and forty four naira twenty $\mathrm{kobo}^{28}$. A material obtained online says that if one possesses silver, gold and wealth but individual amounts are not equivalent to nisab, then the value of the gold, silver and wealth should be combined. If the combined amount is then equal to nisab of silver, then Zakat is obligatory $(\text { fard })^{29}$. 


\section{A. A. Akanni}

Nevertheless, the Qur'an has specified who the recipients of Zakat should be. Qur' an 9:60 says:

Alms are for the poor and the needy, and those employed to administer it (i.e. the funds), for those whose hearts have been (recently) reconciled (to truth); for those in bondage and in debt; in the cause of God, and for the wayfarer. (Thus is it) ordained by God, and God is full of knowledge and wisdom

According to Chapra, zakat is a social self-help measure adopted with full religious backing to support those poor and destitute who are unable to help themselves to eliminate misery and poverty from the Muslim society ${ }^{30}$.

On the disbursement of zakat, Gusau writes that early literature in general, insist on direct transfer to the beneficiaries, although a few ulema have allowed for indirect transfer in given circumstances ${ }^{31}$. But contemporary jurists and economists accept transfer through subsidizing education, medical facilities, etc. for the poor. Yet others recommended direct transfer to some categories of zakat recipients. Faridi also writes that transfer payments are the best mode of zakat disbursements in certain cases such as debts, accidents, starvation, old age, support etc ${ }^{32}$. He writes further on the uses of zakat funds:

The most important aspect of the matter is the mode of disbursement of zakat funds. The simplest method is to expend these funds through transfer payments to those entitled to receive them. But a deeper understanding of the objectives of zakat, in the light of modern economic analysis, makes its utilization possible in such a manner as to produce a cumulative effect on poverty and an instrument of active fiscal policy designed to promote the welfare function of public expenditure. These funds or a part thereof may be 


\section{A Model for the Administration of Zakat}

earmarked for productive investment intended for the benefit

of eligible recipients in firms or industries owned by them ${ }^{33}$.

Faridi observes further that zakat funds may also be allocated to those avenues of public expenditure, which improve the working conditions and the efficiency of the eligible recipients. "Improved housing facilities, health services, training programmes, education and a number of similar services may be initiated for this purpose. In this fashion, the welfare function of public expenditure would be promoted"34. He concludes by noting that the Islamic fiscal policy based on zakat would provide the state with a reasonable minimum of resources intended for social welfare. Thus, zakat funds can be used in so many ways to benefit the recipients among who are widows, orphans and the aged.

Going by the dictates of Shariah above, the next section of the paper examines how zakat is presently being administered in (Southwestern) Nigeria before suggesting operational guidelines for a better adminisration.

\section{Administration Of Zakat in Southwestern Nigeria}

As noted above, zakat is to help the weak members of the society participate in the activities and have the living conditions and amenities, which are considered minimal in the societies to which they belong. It will achieve this purpose if administered the way it has been commanded by God in Qur' an 9.60 - to be collected and disbursed to the beneficiaries by the machineries of the state. Where there is no Islamic government, it is expected to be administered by an organised body put in place by Muslims. But unfortunately, as noted by Azeez, the administration of zakat in Nigeria, south - west 


\section{A. A. Akanni}

inclusive is done haphazardly and that is why the majority of Nigerian Muslims suffer amidst plenty despite the fact that most of the richest people in the country are themselves Muslims. He asked, "Is the institution of zakat not serving the purpose it is meant to serve"? He then concludes:

The answer is not far-fetched. The way zakat is administered in this part of the world leaves many things undecided. It is disheartening to note that zakat is administered in Nigeria haphazardly. Everyone pays it the way he deems fit. There is no particular body charged with the responsibility of collecting and disbursing the zakat fund as prescribed by Shariah $^{35}$.

Thus, the haphazard administration of zakat could be responsible for the glaring fact that many Muslims in southwestern Nigeria still live below the poverty line. This personto-person approach in the giving of zakat is not good enough. It is even Islamically illegal and unlawful. This is because zakat is to be administered by the state. Ali observes that zakat is not simply an obligatory charity. It is a state institution or where there is no Muslim state, a national institution ${ }^{36}$. The individual is not, therefore, at liberty to calculate and spend his zakat as he likes. It must be collected by the state or on a national basis and spent by the state or community. Ali submits:

Where the Holy Qur'an describes the main heads of expenditure of zakat, it mentions an item of expenditure on officials appointed to collect and distribute the same, which shows clearly that, it contemplated either a department of the state or at least a public fund managed entirely by a public body. The donor is not required to give a certain portion of his savings to deserving person, but to contribute the same to a fund which must be used for the upliftment of the community $^{37}$. 


\section{A Model for the Administration of Zakat}

Thus, the payer of the Islamic tax of zakat is not expected to give it to individuals who to him deserve it. Rather, he should pay it to the common purse of the Muslims. It was in this sense that the Holy Prophet Muhammad (SAW) understood and practised it as the head of the Muslim empire. Abu Bakr who succeeded him also understood and practised it in this manner. That was why he used the state law enforcement agencies to compel those who rescinded in its payment to pay it to the purse of the Muslim empire after the demise of the Prophet Muhammad $^{38}$.

Experience in the southwestern Nigeria has shown that shortly after the fasting period, wives of some of those Imams suddenly turned into sellers of food items. As Ambali submits, many of them sell the food items collected at reduced price ${ }^{39}$. It is believed by many that most of such food items are proceeds from Zakat ul-fitr, which their husbands might have collected during the month of Ramadan.

From the above, it is clear that by Law, zakat cannot be paid directly to the beneficiary; it must be paid to the government under the Shariah and where Shariah is not in place, to an agency of government or a body instituted for that purpose. In the absence of all these in the south western Nigeria as noted earlier, the few Muslims in the zone who pay zakat give it to their Imams for onward distribution to the beneficiaries. It is among these Imams who are also legal beneficiaries of zakat that it subsequently devolves. Azeez observes:

On many occasions, some payers give their zakat to local mallams and clerics for onward distribution to the deserving beneficiaries. The latter, in most cases, use the money for personal comfort, such as buying cars, marrying more wives 


\section{A. A. Akanni}

etc, rather than distributing it to the beneficiaries after taking their own rightful shares ${ }^{40}$.

As a Muslim youth who grew up in the zone, this writer witnessed several occasions in which some Muslim leaders would rise up in the Mosque during Tafsir(exegesis of the Qur'an) sessions in the month of Ramadan to announce that this was someone zakat (without declaring how much the person gave to them). They would then give a naira note say, ten naira (N10.00) to every member carrying a copy of the holy Qur'an. Done this way, there will not be accountability on the one hand and on the other hand, zakat will not achieve its aim of alleviating poverty among Muslims. This is because it is given or disbursed the way Sadaqah is disbursed. Hence, Oloso remarks: "They also must have noted that despite their constant giving of charity, beggars continue to intimidate them at their doors as if what they give provides no succour. This is because Sadaqat or charity has not the great effect of $z a k a t{ }^{\prime 41}$.

The experience of the early Muslims shows that zakat was efficiently administered. For example, during the time of 'Umar ibn Abdul Azeez, people were enriched through zakat fund to the extent that within a short period of time, there was no poor man who would collect zakat ${ }^{42}$. Caliph Ali ibn Abi Talib was also reported to have said: "He (a Muslim leader) is to give them alms so that they will become free of want" ${ }^{43}$. Caliph Umar ibn $\mathrm{Al}$ - Khattab was also quoted as saying: "When distributing Zakat to the poor, give them in abundance so that they are satisfied, repeat giving them even if one has to get a hundred camels ${ }^{44}$.

It must be added that it is not wrong for the Imams to benefit from the proceeds of zakat. In fact, they are legal 


\section{A Model for the Administration of Zakat}

beneficiaries if considered as zakat administrators who the Qur' an (9:60) identifies as a category of beneficiaries of zakat. But holding on to everything or the larger percentage of it is what is frowned at.

\section{Towards a Just Administration of Zakat in Southwestern Nigeria}

From the above, one can see that zakat is not being properly administered generally in Nigeria and particularly in the southwest as dictated by the Shariah. This section of the paper provides the operational guidelines for the just administration of the Islamic tax in the region according to the dictates of the Shariah.

Because there are many ways to skin a cat, the administration of zakat in the southwestern Nigeria may take two dimensions/perspectives. One is to take advantage of the various Muslims organizations to collect and disburse it; the other is to establish a board for its administration in the region. As for the use of the Muslim organizations, one will realize that it has become fashionable for Muslims in the region to belong to one Muslim organization or the other. The Muslim organizations are those formed in response to the sociopolitical and religio-spiritual challenges Muslims in the region faced at one time or the other. Some of those organizations include the Ansar ud-deen Society of Nigeria, the Nawair uddeen Society of Nigeria, the Islahudeen, Da'wah Front and more recently NASFAT and Quareeb Society of Nigeria. Most of those organisations meet regularly, especially on Sundays to teach and educate their members on salient issues on the practice of the religion. Muslims in the region are so committed to the idea of identifying with one Muslim organization or the 


\section{A. A. Akanni}

other that those who do not belong to any are seen, though wrongly, as undermining an important aspect of the religion. In fact, every Sunday morning between 7.00a.m to 12 noon, Muslim faithful are seen in white attires moving with their families to attend the Assalatu session of one organization or the other. The period corresponds with the time when most Christians attend church services and appears to be a way of checkmating the evangelical efforts of their Christian counterparts who invite Muslims to the church as this period. The commitment Muslims in the geo-political zone now have to those organizations is so great that the leadership of these organizations moderates their social-political and educational lives. These Muslim organizations therefore, constitute veritable avenues for the collection and disbursement of zakat as both benefactors and beneficiaries are found among members of the organizations. The cooperation of the local Imams behind who these people worship at home will however be required in educating the people on the significance of zakat.

The other perspective by which zakat can be justly administered in a multi-religious environment like the southwestern Nigeria is to establish a board for that purpose. The board to be named Zakat Trust Fund or any name that best suits is to be registered with the country's Corporate Affairs Commission in order to provide legal and social controlling force to such Muslims' actions. This is necessary especially in an environment that is characterized by high level corruption. The board will have its offices in each of the states of the federation for easy contact and administration of the fund raised into its purse. Committed and professional Muslims whose careers have to do with the items and administration of 


\section{A Model for the Administration of Zakat}

zakat should be named as members and staff of the board. As in the first option, this approach will also require the support of the ratibi (community) Imams in educating the Muslim populace on the significance and merits of paying zakat. This massive and aggressive education of Muslims on the significance and merits of zakat lies heavily on the local Imams behind who the Muslims observe their daily prayers in their various localities. To achieve success in this direction, the League of Imams and Alfas, which is the umbrella organization for all Imam and Alfas in the Southwestern Nigeria could rule that it forms part of the weekly Friday sermon. That will be perfectly correct under the Istihsan (Public Interest) in Islamic jurisprudence. ${ }^{45}$ Electronic and print media could also be used to achieve this massive and aggressive education. At the organizational level, pamphlets and handbills could also be used. All these put together will achieve remarkable results in terms of awareness which is the basic problem associated with the payment of zakat in the geo-political zone.

After much awareness has been created, both the Muslim organizations and the Board can undertake the following steps:

1. Design forms for the collection of zakat. Particulars of the benefactors such as name, address etc should not be requested to protect them from fraudsters. Serial numbers could be attached to the forms with corresponding numbers on the counterfoils for easy reference. The content of the form will find out the source(s) of income of the benefactors and the revenues accruing from each of the sources. These are to enable the board or the organization help the benefactors determine whether the source(s) of income are zakatable or not, the "nisab" of the amounts 


\section{A. A. Akanni}

involved and how much is payable as zakat, and when the sources are zakatable. Specifying the amount accruing from each of the sources can, however, be made optional in order to further protect the benefactors from fraudsters. Provision of guidelines on how to determine the nisab will, however, be necessary to guide the benefactor to determine what is zakatable and what is payable on their own. It is hoped that benefactors will be faithful to their Creator who knows and sees everything in this respect. It needs be added that this form can be obtained and submitted in person or by proxy or online from the board or the Muslim organization that is handling it.

2. Determine and publicise the nisab of each zakatable item and what is payable on each to the Muslim populace on a monthly basis.

3. Request individual wealthy Muslim to choose a month of his or her choice in which he/she will be paying zakat. This request can be made on the media, pulpits, through pamphlets, handbills and on the form designed for that purpose. The month of Ramadan or individual's month of birth could be suggested so that something peculiar to that month will serve as a reminder.

4. Whatever is to be paid as zakat should be paid directly into bank accounts of the respective organizations or board. The bankers of the board or organization should be carefully selected and run to avoid usury and corruption which are vehemently abhorred by the Shariah.

5. Design a forms for the beneficiaries, set criteria for eligibility within the provisions of Qur'an 9: 60, develop a process of selection and faithfully implement the decisions of the board on these. 


\section{A Model for the Administration of Zakat}

6. Set a day aside, probably in the month of Ramadan as "Zakat Day". Activities of the day could include reports on how the zakat collected the previous year was expended, testimonies from beneficiaries, paying and collection of zakat from willing payers and special prayers ( $d u a)$ for the benefactors, beneficiaries and administrators etc. The event should be made a jamboree of a sort. The general public should be invited hence, great publicity should be given to the programme.

\section{Conclusion}

From the foregoing, one can see that administration of zakat in a multi-religious society is not only possible but easy. Muslims, wherever and in whatever condition they find themselves must strive to practise this tenet of their religion. The example of this is given by Allah when Muslims are urged to observe the canonical prayers in whatever condition they find themselves - even in times of difficulty and fear (Qur'an $2: 234)$. The issue of zakat cannot be different. The silly excuse of not being under an Islamic government does not absolve Muslims of the socio-religious obligation of justly administering the zakat. The blame, as perceived by man and the sin as will be treated by Allah will be jointly shared by the wealthy Muslims who are to pay the zakat, the Imams who are to preach it and the Muslim leaders who are to administer it. Even the poor man who is to benefit from it also has his own share of the blame and the sin because as a Muslim, he is under obligation to correct the ills of the society for as much as it is within his powers ${ }^{46}$. 


\section{A. A. Akanni}

\section{References}

1. wysiwygz:/bodyframe.4/http://ehost..rm=Islam, assessed 5/10/01

2. Muhammad Ali, The Religion of Islam, New Delhi: Taj Company, 1986, p. 472

3. Muhammad Muhsin Khan, The Translation of the meaning of Sahih al Bukhari, Beiruit: Dar al Arabia, n.d, p.272

4. Muhammad Sa'eed Dabas and Jamal al Din Zarabozo, Fiqh ussunna (Alms tax and fasting), (tr.) American Trust Publications, n.d, p. 189.

5. Abdul Hamid Siddiqi, Sahih Muslim, Lahore: Sh. Muhammad Ashraf, 1972, p. 465

6. Al Tayib Zein Al Abdin, "Zakat and its Alleviation of Poverty in the Muslim World", Hamdard Islamicus, vol. xx, no 2, April-June, 1997, p.72

7. Andrew Pippin, Muslims: Their Religious Beliefs and Practices: The Comtemporary Period, vol. 2, London: Routledge, 1993, p.136

8. Muhammad Rahimuddin, Muwatta’ Imam Malik, vols. 1\&2, 1985, p. 277

9. M. A. Ambali, Zakat: The Third Pillar of Islam, Ijebu Ode: Shebiotimo Publications, 2006/1427, p. 27

10. ibid, p. 28

11. ibid. p. 28

12. Charles Hamilton, The Hedaya, New Delhi: Nusrat Ali Nasri for Kitab Bhavan, 1979, p.22

13. Khan, Sahih al Bukhari, pp. 275-338

14. C. G Weeramantary, Islamic Jurisprudence: An International Perspective, London: Sarvodaya Vishva Lekha, 1999, p. 60

15. Pippin, Muslims: Their ReligiousBeliefs..., p. 233

16. Sule Ahmed Gusau, "Zakat: A Review of Theory and Evidence", The Muslim World League Journal, vol.25, no.8, p. 21

17. ibid, pp. 21-22 


\section{A Model for the Administration of Zakat}

18. Ziauddin Ahmad, "Nisab of zakat", Islamic Studies, vol. xx, no. 3, pp. 240

19. Ambali, Zakat, p. 27

20. ibid, p. 28

21. ibid, p. 28

22. ibid, p. $32-33$

23. K. A Balogun, Islam and World Peace, $41^{\text {st }}$ Inaugural Lecture, Olabisi Onabanjo University, Ago Iwoye, Nigeria, 2006, p. 20

24. Ambali, Zakat, p. 29

25. A. A. Akanni, "Shedding Light on the Value of Moon sighting in Islam", Journal of Arts and Social Sciences, vol. 4, November, 1998 , p.339

26. ibid, p. 37

27. Ambali, Zakat, p. 22

28. Ambali, Zakat, p. 27

29. http:/www.uwt.org

30. Muhammad Chapra, "Activation of Zakat System", The Muslim World League Journal, November, 2004, p. 45

31. Gusau, "Zakat: A Review of..., p. 22

32. F.R Faridi, "Zakat and fiscal policy" in K. Ahmad (ed) Studies in Islamic economics, (pp.20-29), Leicester: The Islamic Foundation, (1980), p. 129.

33. ibid, p. 127

34. ibid

35. W.O. Azeez, "Zakat as an Islamic Social Insurance", Al Hadarah: LASU Journal of Arabic and Islamic Studies, vol. ix, 2003, p.34

36. Ali, The Religion of Islam, p. 472

37. ibid, p. 467

38. I. A. B Balogun, "Zakat: A Welfare Institution for Muslims", ZACAIS Journal of the Humanities, vol. 1, 1996, p.126

39. Ambali, Zakat, p. 34

40. Azeez, Zakat as an Islamic Social Insurance", p. 34

41. K. K. Oloso, "Zakat as a Prime Poverty Alleviator" in Z. I. Oseni, (ed) Fluorescence of Arabic and Islamic Studies in Nigeria (Festschrift in honour of Professor Wahab O. A. Nasiru), Ibadan: HEBN Publishers PLC, 2008, p. 131 


\section{A. A. Akanni}

42. Riddah M. Larry, "Islamic Solution to Poverty Problem: Were Poverty a man, I would have killed him", The Muslim World League Journal, vol. 23, no 10, March, 1996, p.5

43. Zein Al Abdin, "Zakat and its Alleviation of Poverty..., p. 79

44. ibid, p. 78

45. Imran Ahsan Khan Nyazee, Islamic Jurisprudence, Pakistan: The International Institute of Islamic Research Institute and Islamic Research Institute, 2000, p. 234-235

46. Y. A Quadri, The Sayings of the Prophet (SAW), Ijebu- Ode: Shebiotimo Publications, 1995, p. 35 